\title{
P38 MAPK Inhibitor LY3007113
}

National Cancer Institute

\section{Source}

National Cancer Institute. p38 MAPK Inhibitor LY3007113. NCI Thesaurus. Code C99134.

An orally active p38 mitogen-activated protein kinase (MAPK) inhibitor with potential immunomodulating, anti-inflammatory, and antineoplastic activity. Upon administration, LY3007113 inhibits the activity of p38, thereby preventing p38 MAPK-mediated signaling. This may result in the inhibition of the production of proinflammatory cytokines and the induction of tumor cell apoptosis. p38 MAPK, a serine/threonine protein kinase often upregulated in cancer cells, plays a crucial part in the production of a variety of cytokines involved in inflammation and cellular proliferation such as tumor necrosis factor (TNF) and interleukin (IL)-1 and -6. 